IRSTI 10.79.21

\author{
Mukhamadyeva G.N. ${ }^{1}$, Atakhanova G.M. ${ }^{2}$, Timchenko K.S. ${ }^{3}$, \\ Yergali A.M. ${ }^{4}$, Kevin M. Beaver ${ }^{5}$ \\ ${ }^{1}$ Associate Professor, Candidate of Law \\ ${ }^{2}$ Associate Professor, Candidate of Law \\ ${ }^{3}$ Master of Laws, Lecturer \\ ${ }^{4} \mathrm{PhD}$, associated professor \\ al-Farabi Kazakh National University, Kazakhstan, Almaty \\ ${ }^{5} \mathrm{PhD}$, Judith Richard Harris of Florida State University College of Criminology and CJ, \\ ???????????????

\section{RIGHT TO PERSONAL FREEDOM AS THE BASIS \\ OF THE PRINCIPLE OF THE INVIOLABILITY OF THE PERSON IN CRIMINAL PROCEEDINGS}

The article deals with the issues of balancing the interests of the individual and the state, most clearly manifested in the criminal process, on the example of the implementation of the principle of personal immunity. In this regard, the author updates: the essence, importance and role of: the measures of criminal procedural coercion applied by the state, in particular, the bodies of criminal prosecution, which boil down to ensuring state law and order; the principle of the inviolability of the person as the fundamental and leading principle of the entire criminal process of the Republic of Kazakhstan. For this, the work examines the theoretical and historical - legal foundations of the integrity of the person as a category of state - legal science, as well as the legal basis of the inviolability of the person as a principle of the criminal process of the Republic of Kazakhstan.

The achievement of this goal contributes to the formulation of the following tasks: identification of the category of personal immunity as a human right in a democratic state; analysis of international legal norms and legislation of the Republic of Kazakhstan regulating the right to the integrity of the person; analysis of the norms of the Constitution of the Republic of Kazakhstan on the human right to personal freedom as the basis of the principle of the integrity of the person; legal assessment of the integrity of the person as a category of criminal procedural science, the principle of criminal procedural legislation.

In the study of the questions posed, a logical, formal legal, analytical, and also functional method is used, identifying the qualitative characteristics of the subject of the study, allowing to determine the essence of the institution under study, the possibility of the regulatory impact of constitutional and sectoral legislation on the state of law and order in the Republic of Kazakhstan. The scientific analysis undertaken by the author is consistently carried out and productively combines the principles of comprehensiveness (the study of the integrity of the person as a constitutional right), and systemicity (the principle of the criminal process), which made it possible to more fully, scientifically actualize the issues of improving the criminal procedure for the implementation of the principle of personal integrity.

Key words: human rights, the right to liberty, the inviolability of the person, measures of criminal procedural coercion, the principle of inviolability of the person, criminal procedure. 


\author{
Мухамадиева Г.Н. ${ }^{1}$, Атаханова Г. М. ${ }^{2}$, Тимченко К.С. ${ }^{3}$, \\ Ергали А.М. ${ }^{4}$, Кевин М. Бивер \\ ${ }^{1}$ профессор м.а., 3.Ғ.к. \\ ${ }^{2}$ професссор м.а., 3.F.К. \\ зоқытушы, з.ғ.м. 4Аоцент м.а., PhD-Аокторы \\ әл-Фараби атындағы Қазақ ұлттық университеті, Қазақстан, Алматы қ. \\ ${ }^{5}$ Ажудит Рич Хариис атындағы Флорида университетінің (АҚШ) криминология және \\ қыммыстық сот төрелігі комлеАжінің профессоры, PhD-докторы,

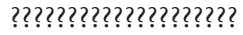 \\ ???????????? \\ ???????????????????
}

Мақалада жеке басқа қол сұқпаушылық қағидасының жүзеге асырылу мысалында, қылмыстық іс жүргізуде анық байқалушы, мемлекет пен тұлға мүАлелерінің теңгерімділігі мәселелері қарастырылады. Осыған байланысты автор өзекті қылады: мемлекеттік органдармен, соның ішінде қылмыстық қудалау органдарымен қабылданатын, мемлекеттік заңдылықты және құқықтық тәртіпті қамтамасыз етуге саятын қылмыстық-процессуалдық мәжбүрлеу шараларының; ҚР-ның қылмыстық іс жүргізудің негізін қалаушы және бастама негіз ретінде жеке басқа қол сұқпаушылық қағидасының мәнін, маңызын және рөлін. Бұл үшін мақалада мемлекеттік-құқықтық ғылым категориясы ретінде жеке басқа қол сұқпаушылықтың құқықтық негіздері, сондай-ақ қылмыстық процестің қағиласы ретінде жеке басқа қол сұқпаушылықтың құқықтық негізі зерттеледі. Қойылған мақсаттарға жетуге мынадай міндеттер қойы^ды: Аемократиялық мемлекетте аламның құқығы ретінде оның жеке басқа қол сұқпаушылық категориясын тұжырымлау. Жеке басқа қол сұқпаушылықты құқықты реттеуші халықаралық құқықтық нормалар мен ҚР-ның заңдарының арақатынасын анықтау; жеке басқа қол сұқпаушылық қағиласының негізі ретінде аламның жеке бостандыққа құқығы туралы ҚР-ның Конституциясының нормаларына талдау жасау; қылмыстық-процестік ғылымның категориясы, қылмыстық-процестік заңның қағидасы ретінде жеке басқа қол сұқпаушылықұа құқықтық баға беру; Қойылған мәселелерді зерттеуде сонымен қатар, ^огикалық, формалды-құқықтық; аналитикалық; зерттеудің пәнінің сапалы сипаттамасын ашушы, зерттелуші институттың мәнін анықтауға, Қазақстан Республикасында заңдылық, және құқықтық тәртіп жағдайына конституциялық, және салалық заңдардың жүйелі әсер етуіне мүмкіндік беретін функционалды әдіс қолданылады.

Автордың ғылыми талдау жасау талпынысында кешенділік (конституциялық құқық, ретінде жеке басқа қол сұқпаушылықты зерттеу) және жүйелілік (қылмыстық процестің қағидасы) қағидалары жүйелі жүзеге асырылып, тиімді үйлесімін табады, бұл жеке басқа қол сұқпаушылық қағидасының жүзеге асырылуы үшін қылмыстық-процестік мүмкіндіктерін жетілдіру мәселелерін аса толық ғылыми өзекті етуге жол ашады.

Түйін сөздер: адам құқықтары, бостандыққа құқық, жеке басқа қол сұқпаушылық, қылмыстықпроцестік мәжбүрлеу шаралары, жеке басқа қол сұқпаушылық қағидасы, қылмыстық, іс жүргізу.

\author{
Мухамадиева Г.Н. ${ }^{1}$, Атаханова Г.М. ${ }^{2}$, Тимченко К.С. ${ }^{3}$, \\ Ергали А.М. ${ }^{4}$, Кевин М. Бивер \\ ${ }^{1}$ К.ю.н., и.о. профессора \\ ${ }^{2}$ К.ю.н., и.о. профессора \\ ${ }^{3}$ магистр юридических наук, преподаватель \\ ${ }^{4}$ Аоктор $\mathrm{PhD}$, и.о. Аоцента \\ Казахский национальный университет им. аль-Фараби, Казахстан, г. Алматы \\ ${ }_{5}$ Аоктор $\mathrm{PhD}$, профессор, колмеАж криминологии и уголовной правосудии \\ университета Флориды имени Ажудит Рич Харииса, \\ США, ????????????

\section{Право на мичную свободу как основа принципа неприкосновенности кичности в уголовном процессе}

В статье рассматриваются вопросы сбалансированности интересов кичности и государства, наиболее ярко проявляющиеся в уголовном процессе, на примере реализации принципа неприкосновенности мичности. В Аанной связи автор актуализирует: суть, важность и роль: применяемых государственными, в частности органами уголовного преследования, мер уголовно-процессуального принуждения, сводящегося К обеспечению государственной законности и правопорядка; принципа неприкосновенности кичности как основополагающего и руководящего начала всего уголовного процесса Республики Казахстан. А^я этого в работе исследуются теоретико- и историко-правовые основы неприкосновенности кичности как категории государственно-правовой науки, а также правовые основы неприкосновенности 
мичности как принципа уголовного процесса Республики Казахстан. Аостижению поставленной цели способствует постановка следующих задач: выявление категории неприкосновенность мичности как права человека в демократическом государстве; анализ международных правовых норм и законодательства Республики Казахстан, регулирующих право на неприкосновенность личности; анализ норм Конституции Республики Казахстан о праве человека на личную свободу как основы принципа неприкосновенности кичности; правовая оценка неприкосновенности мичности как категории уголовно-процессуальной науки, принципа уголовно-процессуального законодательства.

При исследовании поставленных вопросов используются логический, формально-правовой, аналитический, а также функциональный метод, выявляющий качественные характеристики предмета исследования, позволяющий определить суть исследуемого института, возможность регулятивного воздействия конституционного и отраслевого законодательства на состояние законности и правопорядка в Республике Казахстан. В предпринятом автором научном анализе последовательно осуществляются $и$ продуктивно сочетаются принципы комплексности (исследование неприкосновенности кичности как конституционного права) и системности (принципа уголовного процесса), что позволи^о более полно, научно актуализировать вопросы совершенствования уголовно-процессуальных возможностей Аля реализации принципа неприкосновенности мичности.

Ключевые слова: права человека, право на свободу, неприкосновенность кичности, меры уголовно-процессуального принуждения, принцип неприкосновенности кичности, уголовный процесс.

\section{Introduction}

The fundamental category underlying the integrity of the person is, of course, the status of the person. The status or legal status of an individual is predetermined, first of all, by the political and legal regime in the state and is established in its Basic Law. In Kazakhstan, the process of establishing the status of an individual went through bright evolutionary stages. Today, we speak about the status of a person from the position of observing its democratic rights and freedoms and legitimate interests. We can talk about personality as a system-forming category only when it has enough freedom in society. Moreover, in order to protect their freedoms, an individual is endowed with a certain amount of rights in the state (part 1 of art. 18 of the Constitution of the Republic of Kazakhstan).

However, we do not speak about the integrity of the person as a self-sufficient category, its truly democratic nature requires constant scientific, practical and dialectical development, taking into account all developing public relations, enhancing the role and importance of individual status.

The content of the inviolability of the person as a right is disclosed through a system of constitutional norms establishing: the right to personal freedom (art. 16); the right to life (art. 15); the right to privacy, personal and family secrets, protection of their honor and dignity (art. 18); equality before the law and the court (ch.1 art.14); prohibition of discrimination on grounds of origin, social, official and property status, gender, race, nationality, language, attitude to religion, persuasion, place of residence or for any other circumstances (ch.2 art. 14) ; inviolability of dignity (ch. 1 art. 17); prohibition of torture, violence, other cruel or degrading treatment or punishment (ch. 2, art. 17) and others.

In a number of countries, it is believed that human rights are natural, intrinsic to its essence and not derived from power. It is characteristic that many movements in defense of freedoms, for example in England, were based on the idea of "restoration" (renovatio) of rights, even if these rights had not been recorded anywhere before (Barg M.A., 1991: 20).

If rights belong to a man by virtue of his nature, then the state cannot be considered their source. The person is not obliged to the state of his freedom. From this it follows that the function of the state is mainly to protect individual freedom from encroachment, as well as to establish some restrictions and frameworks that streamline the exercise of rights. Therefore, the state must determine the limits of safe use of freedom, since freedom, with the exceptions that the state has established, belongs to man. The boundaries beyond which a person becomes "vulnerable" or "reachable" for a state that uses a system of measures of coercion must be clearly outlined in the law. Beyond these limits, the freedom of the individual is limited, and in case of violations of these restrictions, legal liability measures are applied to the latter.

At the same time, the issue is very important that both limitations and responsibility as a response measure for a violation are established from the 
position of equality. This criterion determines the essence of the rule of law, in which law is a common and equal "measure" for the life of society. An example is the rule of the Constitution, which establishes: "Everyone is equal before the law and the court" (ch. 1 art. 14). If a person has a constitutional right to immunity, then the state is obliged to guarantee its implementation in relation to each individual. This provision is particularly relevant in circumstances where a person falls within the scope of criminal legal influence. Therefore, the inviolability of the person as a right is transferred to a different quality and becomes the predetermining and fundamental principle of the criminal process.

The determination of the inviolability of the individual is complicated by the quality of the individual's status in society, the guarantees, the means of protection and protection with which this or that state has given it. In a democracy, personal integrity is given special attention. Even the commission by a person of the most serious crime, in many developed countries, is not a basis for applying the death penalty in accordance with the principle of humanism and the goals of criminal punishment. The same trend is observed in the Republic of Kazakhstan. By the abolition of the death penalty, our state is "taking the right steps". In 2003 in the Republic of Belarus, in order to further humanize the state's criminal policy and in accordance with ch. 1 of art. 15 and ch. 2 of art. 40 of the Constitution introduced a moratorium on the death penalty until the question of its complete abolition is resolved (Decree of the President of the Republic of Kazakhstan, December 17, 2003 N 1251).

The status of an individual is determined through the totality of its legal rights, freedoms and duties in the state, which relate to its interests in security, social security, cultural, political, economic selfexpression, etc. Some of the rights of an individual belong to it from birth, they are inalienable, absolute and inviolable to any or encroachment on the part of the state, its bodies and other individuals, its collective formations. Immunity is thus identified with such concepts as "it cannot be encroached", "it cannot be broken". Literally, inviolability means: "you cannot touch", but touch in the sense that as a result of such a touch, in any way, the extent of rights and freedoms that is outlined by the law.

"Individual freedom forms the basis of civil society. It puts every person in a position in which he views another person not as the exercise of his freedom, but on the contrary, as its limits" (R.A. Mullerson, 1991, p.43). Some philosophers define freedom as rule over circumstances with knowledge of the matter. ( M.V. Popov, 2010, p. 13), while others, like Schelling, argue that freedom - is the ability to make choices based on the distinction between good and evil (New Philosophical Encyclopedia, https://ru.wikipedia.org). If necessity is not yet known, then it conflicts with the aspirations of the subject. The ratio of these categories reflects the internal, subjective side of the mechanism of criminal procedural coercion. In the categories of possibility and reality there is an objective beginning, according to which, due to a number of circumstances, among the many possible options for the subject is predetermined by one definite, I answer interests of society, of all objective natural sciences. torus process. The circumstances depend on the economic political, ideological factors that characterize specific social system.

Freedom of the individual in society is measured by many indicators, since legal freedoms represented as subjective rights are also included in the general legal status of the individual. So, in particular, it can be a freedom of speech, reflecting its political right; freedom of creativity, including the cultural interests of the individual. In civil law relations, the slogan acts: "Everything is allowed that is not prohibited by law."

We find the confirmation of our own judgment by examining the works of M.S. Strogovich, who notes that "Freedom of the individual is also her right." On the other hand, "any individual right includes a certain freedom in behavior, that is, a certain sphere of possibilities, within which a person chooses a particular form of behavior, decides how he should act - otherwise it would not be a right, but an obligation " ( M.S. Strogovich, 1981, p. 24 ) . Russian theorist of law N.I. Matuzov writes: "... When the legislator wants to grant freedom, he grants the right. Actually, freedom in a legal sense is a subjective right, and vice versa, a subjective right is a legally guaranteed freedom "( N.I. Matuzov, 1972, p. 250 ) .

However, it is necessary to realize the category that there is no absolute freedom anywhere in the world. The measure of individual freedom is directly related to the level of freedom of society. Lich ness cannot be free from society just as it cannot be free from nature. It is clear that a person is free in society as far as the level of freedom of the society itself allows. Human rights are as real as society can provide them, as far as it is concerned in this. Of course, the action of this pattern is not exceptional: the most important role belongs to the personality itself, its qualities, its activity. But go deliver it to society the 
independence of the results of the implementation of its rights from the social environment means to foresee the possibility of injustice in this area.

Thus, the freedom of the individual is not unlimited. Restrictions are primarily associated with the need to ensure public order, the rights and freedoms of other individuals, state, environmental security, preservation of the constitutional order, international consent, etc. However, these restrictions are not unlimited either. For example, in accordance with ch. 3 of art. 39 no restriction of the rights and freedoms of citizens for political reasons is allowed in any form. In no case shall the rights and freedoms provided for in art. 10, 11, 13-15, ch. 1 of art. 16, art. 17, art. 19, art. 22, ch. 2 of art. 26 of the Constitution. In this case, we are talking about the legislative (constitutional guarantees) of the rights and freedoms of a person and citizen, which protect them as much as possible from the use of state coercion measures against them.

Nevertheless, we will continue the study of freedom as the basis of the principle of the inviolability of the person. What is the freedom of an individual involved in the field of criminal proceedings? After all, it is in this area that a person acquires a specific criminal procedural status and falls under the action of the "most severe" criminal system of state coercion. Until the defendant is found guilty of a criminal offense, the latter is subject to measures of criminal procedural coercion, by which the amount of his personal freedom is significantly limited.

The right-limiting orientation of coercion in the criminal process arises from the general axiom of state coercion, which is viewed as a physical or mental effect by imposing personal, material and moral restrictions in order to subordinate the requirements of the state. It is easy to see that in this definition, the main goal of coercion were exclusively state interests. It seems that this definition does not fully express the essence of coercion, since its right-regulating nature remains in the shadow. One should agree with the Kazakhstani scientist A.N. Akhpanov, who believes that "state coercion should be considered as one of the methods of regulating social relations. Such an understanding of the essence of coercion makes it possible to single out in it the most characteristic, basic quality, which combines both the objective and instrumental purpose of coercive measures. "By purpose, the author understands the "set of tasks solved by state coercion. The instrumental purpose of coercion determines the selection and operation of specific means and methods in order to achieve existing objectives "(A.N. Akhpanov 1997, p. 34 ) .

Appeal to the means of criminal procedural coercion dictated by objective circumstances. But in each case of its application the moral validity of the decision made and the action committed is necessary. A citizen subject to state coercion in the field of criminal proceedings should be aware of his duty to follow the prescription or coercion established by law. At the same time, an official resorting to coercive means must understand the necessity and moral validity of such an impact, not only the legal but also the moral correctness of his actions (T.N. Moskalkova, 1996, p.35]. Important here is the imbalance of interests opposite sides: the state represented by its law enforcement agencies, whose activities are aimed at exposing and punishing the perpetrators, whose interests in the criminal process are reduced to avoiding responsibility.

The criminal procedure law and the suspects and accused persons who have been prosecuted, are endowed with a block of procedural rights, as well as procedural and constitutional guarantees, which determine the extent of their social freedom. It would be appropriate to quote L.D. Vojvodin and M.A. Krasnov, who pointed out that "the right is an opportunity to receive a social benefit, and freedom is an opportunity to commit an action. But every constitutional freedom of a citizen is at the same time his right " (L.D. Voevodin, M.A. Krasnov, 1982, p.9). Thus, the measure of individual liberty in the field of criminal legal proceedings is determined by the totality of its constitutional and procedural rights. For example, the right of a defendant to a defense is the freedom guaranteed by law to refute a charge "(Petrukhin I.L. 1985, p.20), etc.

At the same time, it is necessary to agree with the authors, who consider that freedom and subjective rights are all categories of a different order (I.L. Petrukhin, 1985, p.21). So, in particular, freedom, already in accordance with modern (democratic) legislation, is one of the rights, moreover, this right is included in the category of inalienable and natural rights, which are restricted and restricted only by the state, only in extreme cases and only legally.

Therefore, the application of restrictions is possible only if they are provided by law. However, there are opinions of the reverse order. So, for example, bearing in mind the right of the inviolability of the individual, V.A. Patulin. He believes that "it is completely inadmissible to say that it can be limited by lawful actions of the police, the prosecutor's office and the court. According to the author, in this case, it is not the right to immunity 
that is limited, but the inviolability itself as an actual state" (V. A. Patulin 1973, p. 15).

Today, this position has been refuted not only by the democratic political tendencies of Kazakhstan's society, but also by the practice of legal reformism, which has shown that the basis of the public law and the system of legislation of the Republic of Kazakhstan. The state protects and guarantees the observance of the rights and interests of citizens only if they are established by law. The fundamental principle here is the principle of legality, which heads the system of constitutional and legal principles of domestic legislation. Hence, the freedom of the individual is limited only by the rule of law.

The problem in this case, in our opinion, seems quite different.

First, the mechanism of restriction of rights and freedoms regulated by the norms of law should be applicable (that is, the norms of law should correspond to the social, political, cultural and other conditions of life of the society in which it is currently located). This is the problem of the legislator.

Secondly, the practice of law enforcement must meet the requirements of legality and be accompanied by such requirements to the subjects of law enforcement as morality, professionalism, etc. Here, an important factor is the individual properties of these subjects, such as: decency, sense of duty, education, patriotism, high self- and legal conscience, etc. Violations of rights and freedoms, in particular, and personal immunity, in part, we observe because of the ignorance of law enforcement officers, their poor professional general training, etc.

Often, these individuals violate the law establishing the integrity of the person in criminal proceedings.

Therefore, coercion as a measure of restriction established by the criminal procedure law is justified, despite the fact that it encroaches on the constitutional right to the freedom of the individual. When invoking measures of criminal procedural coercion, the inviolability of the person is referred to, emphasizing the preservation of a certain block of rights and freedoms for an individual, which cannot be limited and violated either by the state or by other subjects of law enforcement.

A striking example today is the legislative regulation of the maximum period of detention prior to indictment and imprisonment; court authorization of arrests; the prohibition of humiliation and the use of violence and torture; increased responsibility for violation of the rights and legitimate interests of citizens in the course of investigative actions; legal support for the supervision and control of preliminary investigations of criminal cases, as well as other guarantees of personal immunity in criminal proceedings.

Analysis of the principles, ideas, norms of the law of the Republic of Kazakhstan shows that they create the space that is necessary for the formation of a civil society, for ensuring the rights and freedoms of man and citizen, for establishing the rule of law, for realizing the political and legal responsibility of citizens, state bodies, officials persons for the coordinated activities of all branches of government.

The doctrine of principles is an essential component of the theory of criminal justice. The level of its development, according to A.V. Grinenko allows to judge the state of legal science in general, as well as the culture of law enforcement (A.V. Grinenko, http://www.pravobooks.ru). It is difficult to disagree with this opinion. The democratic construction of a criminal procedure that ensures the observance of the rights and legitimate interests of citizens in criminal proceedings is based on the principles enshrined in the Constitution and the Criminal Procedure Law. Analysis of criminal procedural principles shows that most of them (competitiveness, legality, personal integrity, equality of rights of a person and a citizen before the law and the court) are guaranteed by the Basic Law of the country and such principles are common law, which is an expression of the nature and essence of a democratic state. These principles recognize a person, his rights and freedoms as the highest value and property of the state. They must operate within the framework of an integrated system of the criminal process, at all its stages. Historically, the forms of the criminal process in various countries have undergone all sorts of changes, it depended on the state structure and the ongoing domestic legal policy. World history confirms the trend. The assertion of the rights and freedoms of man and citizen was preceded by more than one bourgeois revolution. Such developed countries as England (W. Stubbs, 1890, p. 82), USA (Human Rights in the USA, http://wiki-org.ru), France (Absolute Monarchy in France, http://ensiklopedya.ru) (V.E. Rubanik, 2011, p.115) before ensuring the effective implementation of the principle of the inviolability of the person, other democratic rights and freedoms, passed a difficult path, full of conflicts and collisions of interests of the state and its citizens.

One of these principles is the principle of personal immunity. The importance of personal integrity, as shown by the results of this study is so great that (pre) determines the basis of legal status 
in the criminal process. The content of the legal category of personal integrity is multidimensional. Firstly, it is an integral status of the individual, which includes the whole complex of rights and freedoms of the individual. In another capacity, the integrity of the person acts as a guiding, fundamental basis or in other words - the principle of the criminal process.

As a principle of criminal justice, the category of personal immunity applies to all stages of the process and is most relevant when applying measures of criminal procedural coercion. Today, the issue of personal immunity has clear prospects for legal resolution and, this is connected, first of all, with democratic changes in the entire state and legal system of the republic. A person with a complex of his natural, inalienable and acquired rights and freedoms becomes in our state a fundamental principle not only in the regulation of legislative acts, but also in real life conditions. This, in our opinion, contributes to the political and legal course of the development of democratic relations in the republic. The complexity of the chosen path for Kazakhstan is emphasized every time by the dogma of the transitional period, which creates conditions for searches, difficult decisions and indispensable mistakes. This factor is indicated by the results of numerous rounds of legal reforms, the beginning of which was laid back in 1990. However, today we can firmly assert that it is a phased legal reform that can achieve the desired indicators, since The legislator uses in his arsenal not only the rules of the legislative technique, but also the domestic experience of the practice of law enforcement.

The inviolability of the person, being, above all, a constitutional human right, is put by the legislator at the center of the criminal process. And this is due to the increased attention of the state to the individual, despite the fact that she is involved in the sphere of criminal proceedings, where she falls for committing (or suspicion for committing) the most dangerous offenses to society. Here, the main (constitutional) postulate is the nomination of the individual in priority positions in relation to all other state institutions, including the institutions of power (in particular, the penitentiary system).

As far as the inviolability of the person as a legal category, acting in the form of the right of the person, is difficult from the point of view of constitutionallegal science, so much, and perhaps even more, taking into account the sectoral specifics, it is difficult in the criminal process. If the Constitution establishes the right to personal immunity from several norms: the right to life, dignity, security, freedom, etc., then in the criminal process this whole complex also "breaks up" into stages specific to the process, multiple procedural and investigative actions, procedural measures, etc. Moreover, the criminal process consists not only of the principle of the inviolability of the person, but also of other principles, such as the principle of legality (art. 10 of the Code of Criminal Procedure of the Republic of Kazakhstan); comprehensiveness and completeness of the investigation and inquiry (art. 24 of the Code of Criminal Procedure of the Republic of Kazakhstan), equality and competitiveness of the parties (art. 23 of the Code of Criminal Procedure of the Republic of Kazakhstan); presumption of innocence (art. 19 of the Code of Criminal Procedure of the Republic of Kazakhstan), the inadmissibility of repeated conviction and criminal prosecution (art. 20 of the Code of Criminal Procedure of the Republic of Kazakhstan); ensuring the suspect, accused person has the right of defense (art. 26 of the Code of Criminal Procedure of the Republic of Kazakhstan); exemption from the obligation to testify (art. 28 of the Code of Criminal Procedure of the Republic of Kazakhstan); publicity (art. 29 of the Code of Criminal Procedure of the Republic of Kazakhstan); freedom to appeal procedural actions and decisions (art. 31 of the Code of Criminal Procedure of the Republic of Kazakhstan), etc.

The principle of personal immunity is regulated in art. 14 of the Criminal Procedure Code of the Republic of Kazakhstan and has a very important and independent significance for the criminal procedural science.

Firstly, the principle of inviolability determines the legality of restriction of freedom in criminal proceedings, through the application of measures of criminal procedural coercion (detention) (Part 1 of Art. 14 of the Code of Criminal Procedure of the Republic of Kazakhstan ).

Secondly, it limits the period of detention without a court sanction, a person may be detained for a period of not more than forty-eight hours, and a minor - for a period of not more than twenty-four hours.

Thirdly, it establishes a special procedure approved by the (court):

- detention and house arrest;

- compulsory placement of a person who is not in custody in a medical organization for the production of forensic psychiatric and (or) forensic medical examinations (ch. 2 of art. 14).

Fourthly, the principle of the inviolability of the person, established in Art. 14 of the Criminal Procedural Code of the Republic of Kazakhstan 
establishes the responsibility of the bodies carrying out criminal prosecution functions

- the immediate release of an unlawfully detained, or arrested, or unlawfully placed in a medical institution, or held in custody over the period prescribed by law or sentence (part 4 of Art. 14);

- No one of the persons participating in the criminal proceedings may be subjected to torture or other cruel, inhuman or degrading treatment or punishment (Part 5 of Art. 14);

- no one may be involved in participation in procedural acts that create a danger to the life or health of a person ( Section 14, paragraph 6 );

- the detention of a person in custody, as well as a detainee on suspicion of committing a criminal offense, must be carried out in conditions that exclude a threat to his life and health (Part 7 of Art. 14);

- Compensation of harm caused to a citizen as a result of unlawful deprivation of liberty, keeping in conditions dangerous to life and health, and cruel treatment of him (part 8, art. 14).

The construction of the category we are considering in principle means that the integrity of the person:

1) constitutes one of the characteristic features of the criminal process;

2) represents a system of legal norms of the most general nature, which is the basis of criminal procedural legislation;

3) violation of the inviolability of the person may be grounds for the cancellation of decisions made (Criminal procedure - Edited by K.F. Gutsenko, 2005, p.49) .

The functional characteristic of the principle of the inviolability of the person, in the criminal process, in our opinion, is not limited only to the content of art. 14 of the Code of Criminal Procedure of the Republic of Kazakhstan establishing that:

The provisions on the inviolability of the person contains the norms of art. 15 of the Code of Criminal Procedure of the Republic of Kazakhstan "Protection of the rights and freedoms of citizens in criminal proceedings".

The principle in question is also expressed in the requirement of the inviolability of the:

- house (art. 17 of the Code of Criminal Procedure of the Republic of Kazakhstan);

- property (art. 18 of the Code of Criminal Procedure of the Republic of Kazakhstan);

- private life, correspondence, telephone conversations, postal, telegraph and other communications (art. 16 of the Code of Criminal Procedure of the Republic of Kazakhstan).

Analyzing the norms of the Constitution of the Republic of Kazakhstan (art. 16) and art.art. 14 and 15 of the Code of Criminal Procedure of the Republic of Kazakhstan, it is easy to notice that they are duplicated in many points. In our opinion, this is explained by the fact that the legislator first elevated the right to personal immunity to the principle (art. 14), and only then ensured the integrity of the person through the institution of protection of the rights and freedoms of citizens in criminal proceedings (art. 15).

Based on the logic of the present study, the "integrity of the person" is a very complex definition. We tried to give the most complete definition of the inviolability of the person through the norms of the Constitution. The inviolability as a legal category is built up of individual human rights and freedoms, their security and protection in the state. In relation to the criminal process, the inviolability of the person has an intrinsic refraction, but is not limited only to ensuring the rights that are fixed in art. 14 of the CPC. So, in particular, art. 15 is of a generalizing nature and absorbs art. 14, since calls the subject of the legal protection of the rights and freedoms of citizens involved in the criminal process (and includes the right to personal integrity). However, art. 14 does not even include references to Art. 16, 17, 18 of the Code of Criminal Procedure of the Republic of Kazakhstan, despite the fact that the meaning of these articles is the principle of the inviolability of the person.

In this case, on the face of the costs of legislative technology: as a result of the fact that the legislator solves the same problem, in the articles of the law that actually absorb each other, the rules on compensation for harm, as well as on the safety of persons participating in the process, for example, almost literally repeat.

Based on paragraph 8 of Art. 14 and paragraph 2 of Art. 15, it follows that compensation for harm caused as a result of violation of his rights and freedoms during criminal proceedings (including unlawful deprivation of liberty, detention in conditions dangerous to life and health, ill-treatment) is refundable according to the procedure stipulated by the Code of Criminal Procedure of the Republic of Kazakhstan (Chapter 4). In accordance with art. 42 of the Code of Criminal Procedure of the Republic of Kazakhstan the right to compensation for harm comes only after the full or partial rehabilitation of a person. The CPC provides for the responsibility of the body conducting the criminal process to bring 
a formal apology to the rehabilitated (part 1 of art. 44). This provision certainly meets the requirements of ethics of criminal proceedings and respect for human rights.

The institute of compensation for harm is also a subject of civil law regulation. In accordance with Art. 923 Civil Code Hos Aubin h Part "..the state compensates for the harm caused to the citizen as a result of unlawful conviction, unlawful criminal prosecution, unlawful use as a preventive measure of imprisonment, house arrest, a written undertaking not to leave, illegal imposition of an administrative penalty in the form of arrest or corrective work, unlawful placement in a psychiatric or other medical institution .. ".

Further, the issues of compensation for harm by the bodies conducting the criminal process are specified in the Resolution of the Plenum of the Supreme Court of the Republic of Kazakhstan dated July 9, $1999 \mathrm{~N} 7$ "On the practice of applying the legislation on compensation for harm caused by the illegal actions of the bodies conducting the criminal process" in which The bodies leading the criminal proceedings are:

- illegal initiation of criminal proceedings;

- illegal criminal prosecution;

- incorrect application of criminal law when qualifying a crime;

- illegal use of a preventive measure or other measures of procedural coercion provided for by law;

- the maintenance of a person detained on suspicion of committing a crime, or a person in respect of whom an arrest was chosen as a preventive measure, in dangerous conditions for his life and health;

- the compulsory placement of a person who is not in custody in a medical institution for a forensic psychiatric or forensic medical examination in the absence of this court decision;

- the use of violence, cruel or degrading treatment;

- carrying out legal proceedings in conditions that create a danger to the life or health of the persons participating in them;

- making decisions and committing acts that degrade honor or diminish the dignity of a person involved in the criminal process;

- use and dissemination for purposes not provided for by the Code of Criminal Procedure, information about private life, as well as other personal information that the person deemed necessary to keep confidential;
- unlawful conviction; illegal use of compulsory medical measures; illegal use of coercive educational measures and others.

Based on the norms of the Code of Criminal Procedure (art. 39 - 42) and the Civil Code (922, 923), it follows that the damage is compensated only to persons in relation to whom rehabilitation is possible. However, from the point of view of the principle of the inviolability of the person in criminal proceedings, it seems important, in our opinion, to decide whether harm will be compensated to persons who are not subject to rehabilitation. After all, even lawfully detained suspected of a crime and lawfully arrested have the right to the integrity of the person. And if, with the correct application of the rules of the $\mathrm{CPC}$, they were allowed to commit violence dangerous to life and health, degrading honor and dignity ? Here, it is important for law enforcement officers authorized to handle criminal cases to be informed that according to the Plenum of the Supreme Court of the Republic of Kazakhstan of July 9, 1999 N 7 "On the practice of applying legislation on compensation for harm caused by illegal actions of the bodies conducting the criminal process" (Clause 5) and "in accordance with Part 2 of Art. 13 and Part 8 of Art. 14 of the Criminal Procedure Code, detainees, suspects, defendants, defendants and convicts also have the right to compensation for the harm caused to them and in cases where they were subjected to violence or ill-treatment during the course of legal proceedings when decisions or actions of the bodies leading the criminal process were humiliated. their honor and dignity, or when, without the need for the case under investigation, personal information has been collected, disclosed or disseminated, which the person deemed necessary to keep secret, as well as when the person deprived of liberty was kept in conditions that are dangerous to life and health. " Norm art. 42 of the Criminal Procedure Code, therefore, needs to be amended and supplemented in accordance with the Resolution of the Plenum of the Supreme Council of the Republic of Kazakhstan.

If a notice explaining the procedure for compensation for harm rehabilitated or partially rehabilitated is issued with a copy of the acquittal sentence, then in the Resolution itself, and especially in the code, nothing is said about the procedure for compensation for harm to the aforementioned persons.

Thus, summing up the present study, let us point out that human rights, including the right to personal freedom, constitute the legal basis of the 
principle of personal integrity. The principle of the inviolability of the person and the right to the integrity of the person are not the same thing. The right to integrity has a multidimensional content; it consists of several components, which are based on the rights and freedoms of the individual. Moreover, it is necessary to recognize that the right to immunity as such is not established in the Law. Based on the analysis of the norms of the Constitution of the Republic of Kazakhstan, we see that the right to inviolability includes such rights and freedoms as: the right to life; property rights; inviolability of dignity, dwelling, etc. The inviolability of the person means that the law not only protects and protects the rights and freedoms of the individual (all rights and legitimate interests of the individual are protected by law), but also creates a kind of "enhanced mode" of protection, which is realized in strictly defined life situations. One of these situations occurs when an individual falls within the scope of criminal proceedings. Here his rights and freedoms are restricted by the state system of coercion. In such circumstances, the person needs increased legal "attention". Therefore, the right of inviolability of the person in criminal proceedings is erected in the principle according to which the entire system of criminal justice is built.

\section{References}

Absolyutnaya monarhiya vo Francii // http://ensiklopedya.ru

Ahpanov A.N. (1997) Problemy ugolovno-processual'nogo prinuzhdeniya v stadii predvaritel'nogo rassledovaniya. - Almaty: Zhety Zhargy. - S. 176.

Barg M.A. (1991) Velikaya anglijskaya revolyuciya v portretah ee deyatelej. - M.: Mysl'. - 397 s.

Grinenko A.V. Istochniki ugolovno-processual'nyh principov // http://www.pravobooks.ru

Grazhdanskij kodeks Respubliki Kazahstan ot 27 dekabrya 1994 goda № 268-XIII //http://adilet.zan.kz

Konstituciya Respubliki Kazahstan. Konstituciya prinyata na respublikanskom referendume 30 avgusta 1995 goda // http:// adilet.zan.kz

Myullerson R.A. (1991) Prava cheloveka: idei, normy, real'nost'. - M.: Yur.lit. - 160 s.

Normativnoe postanovlenie Verhovnogo Suda Respubliki Kazahstan ot 9 iyulya 1999 goda № 7. «O praktike primeneniya zakonodatel'stva po vozmeshcheniyu vreda, prichinennogo nezakonnymi dejstviyami organov, vedushchih ugolovnyj process» // http://adilet.zan.kz

Novaya filosofskaya ehnciklopediya // https://ru.wikipedia.org

Strogovich M.S. (1981) Obshchie polozheniya teorii prav lichnosti v socialisticheskom obshchestve. V kn.: Prava lichnosti v socialisticheskom obshchestve. - M.: Izd-vo nauka. - S. 272.

Matuzov N.I. (1972) Lichnost'. Pravo. Demokratiya. Teoreticheskie problemy sub"ektivnogo prava. - Saratov: Izd-vo Sarat-go un-ta. - S.294.

Moskal'kova T.N. (1996) Ehtika ugolovno-processual'nogo dokazyvaniya. Stadiya predvaritel'nogo rassledovaniya. - M.: Spark. $-125 \mathrm{~s}$.

Petruhin I.L. (1985) Svoboda lichnosti i ugolovno-processual'noe prinuzhdenie: Obshchaya koncepciya. Neprikosnovennost' lichnosti. - M.: Nauka. S. 239.

Patyulin V.A. Neprikosnovennost' lichnosti kak pravovoj institut // Sov.gos. i pravo. - 1973. №11. - S. 12-20.

Prava cheloveka v SSHA// http://wiki-org.ru)

Popov M. V. (2010) Lekcii po filosofii istorii. - SPb., 2010. - $236 \mathrm{s.}$

Rubanik V.E. (2011) Istoriya gosudarstva i prava zarubezhnyh stran. - SPb.: Piter. - $544 \mathrm{~s}$.

Stubbs W. (1890) Select Charters and Other Illustrations of English Constitutional History. - Oxford. - 552 r.

Ugolovno-processual'nyj kodeks Respubliki Kazahstan ot 4 iyulya 2014 goda № 231-V ZRK // http://adilet.zan.kz

Ugolovnyj process: Uchebnik / Pod red. K.F. Gucenko. - 2-e izd., pererab. i dop. - M.: Zercalo, 2005. - 736 s.

Ukaz Prezidenta Respubliki Kazahstan ot 17 dekabrya 2003 goda N 1251 O vvedenii v Respublike Kazahstan moratoriya na smertnuyu kazn'//http://adilet.zan.kz

Voevodin L.D.. Krasnov M.A. O formah konstitucionnogo zakrepleniya svobody lichnosti v SSSR.// Sov. gos. i pravo. - 1982. №4. - S. 8-9. 